Оксана Юденко, кандидат педагогічних наук, доцент кафедри професійного, неолімпійського та адаптивного спорту Національного університету фізичного виховання і спорту України, м. Київ

ORCID ID 0000-0002-8485-7794

Артур Мартиросян, кандидат наук з фізичного виховання і спорту, доцент; президент Української Федерації регбіліг, тренер національної збірної України з регбіліг, м. Київ ORCID ID 0000-0002-9574-9203 Олександр Петрачков, кандидат педагогічних наук, доцент, полковник

Навчально-науковий інститут фізичної культури та спортивно-оздоровчих технологій Національного університету оборони України імені Івана Черняховського, м. Київ

ORCID ID 0000-0002-6684-1641

Аліна Білоус, магістрант кафедри професійного, неолімпійського та адаптивного спорту Національного університету фізичного виховання і спорту України, м. Київ

ORCID ID 0000-0001-9094-1639

DOI: $10.33099 / 2617-1775 / 2020-02 / 363-377$

\title{
ГОТОВНІСТЬ ФАХІВЦІВ СПЕЦІАЛЬНОСТІ 017 «ФІЗИЧНА КУЛЬТУРА І СПОРТ» ДО ВИКОРИСТАННЯ ЗАСОБІВ РЕГБІ В СИСТЕМІ ФІЗКУЛЬТУРНО-СПОРТИВНОЇ РЕАБІЛІТАЦІЇ УЧАСНИКІВ БОЙОВИХ ДІЙ В УКРАЇНІ
}

У статті авторами розглянуто передумови використання регбі в системі фізкультурно-спортивної реабілітачії учасників бойових дій на Сході Украӥни; визначено, щэо регбі на візках є сьогодні видом спорту, що входить до складу Паралімпійських ігор; відбуваються систематичні змагання спортсменів дефлімпійців; також охарактеризовано сучасні особливості спортивної діяльності в регбі на візах та адаптивного регбі, доведено, що цей вид рухової активності можна включати в систему ФСР військовослужбовців 3 дисфункиіяли. Які виникають внаслідок бойової травми; подано результати дослідження здійсненого протягом 2020 року на базах НУФВСУ та НУОУ імені Івана Черняховського щуодо виявлення ступеню теоретичної обізнаності та готовності застосовувати засоби регбі в системі ФСР під час вирішення професійних завдань фахівцями спеціальності 017 «Фізична культура і спорт».

Ключові слова: готовність; фахівці; фізична культура і спорт; засоби; фізкультурноспортивна реабілітація; учасники; бойові дії. 
Постановка проблеми. Із 2014 року (початок військового конфлікту на Сході України) щорічно систематично зростає потреба у кваліфікованих фахівцях, які б могли якісно та ефективно повертати учасників бойових дій до мирного життя та допомагали б долати наслідки бойової травми засобами фізичної та фізкультурно-спортивної реабілітації.

Аналіз останніх досліджень і публікацій. Слід констатувати, що питання відновлення стану здоров'я військовослужбовців - учасників військових локальних конфліктів лишається беззаперечно актуальною про що свідчить науковий пошук розкритий в таких дослідженнях докторів наук як: Ю.Л. Бриндюков (теорія і практика реабілітації військовослужбовців - учасників бойових дій в системі соціальних служб; 13.00 .05 - соціальна педагогіка, 2018) [0]; Т.М. Дегтяренко (теоретико-методологічні засади управління системою корекційно-реабілітаційної допомоги особам з психофізичними порушеннями; 13.00.03 - корекційна педагогіка, 2012) [0]; а також кандидатів наук таких як: M.I. Гулієв (інвалідність внаслідок бойової травми в Азейбарджанскій Республіці та медико-соціальна реабілітація інвалідів; 2004) [0]; О.В. Кочаргіна (наслідки бойової черепно-мозкової травми та обмеження життєдіяльності у колишніх військовослужбовців працездатного віку в сучасних умовах; 2008) [8]. Окремі аспекти реабілітації ветеранів АТО висвітлено та охарактеризовано у роботах Ю.О. Гріненко (2016) [0]; О.М. Кокун, Н.А. Агаєва, I.О. Пішко, Н.С. Лозінської, В.В. Остапчука (2017) [7]; В.І. Шевчука, В.В. Кравченко, Н.М. Беляєвої, О.Б. Яворовенко (2016) [12].

На офіційній сторінці «Київського міського центру з фізичної культури $\mathrm{i}$ спорту інвалідів «Інваспорт»» [0] зазначається, що для осіб з інвалідністю в умовах сучасного суспільства пропонуються такі різновиди рухової активності як: командні різновиди діяльності (бадмінтон; баскетбол; бочча; волейбол та пляжний волейбол; керлінг; настільний теніс; регбі; футбол; футзал); види спорту (плавання; стрільба з лука; стрільба кульова; легка атлетика; параканоє); єдиноборства та різновиди боротьби (вільна боротьба; греко-римська боротьба; дзюдо; тхеквондо); неолімпійські види спорту та рекреаційні різновиди діяльності (спортивне орієнтування; боулінг; танці на візках; рибна ловля); силові види спорту (армспорт та пауерліфтинг); зимові види спорту та рухової активності (гірськолижний спорт; лижні перегони); інтелектуальні ігри (шахи та шашки). Окремо, як структурні складові адаптивного спорту розглядаємо Дефлімпійські ігри.

Нажаль серед опрацьованої нами літератури та електронних інформаційних джерел, практично відсутні теоретичні та методичні відомості, які б надавали чітке уявлення щодо теоретичних та методичних особливостей побудови системи тренування в адаптивному спорті, а тим більше щодо особливосте застосування засобів регбі в системі фізкультурно-спортивної реабілітації учасників військових локальних конфліктів. Тому всі наукові пошуки у цьому напрямку вважаємо актуальними та своєчасними, враховуючи соціальний та професійно-спрямований запит Національної ради спортивної реабілітації захисників України. 
Мета статті полягає у виявленні ступеню готовності фахівців спеціальності 017 «Фізична культура і спорт» до використання засобів регбі в системі ФСР учасників бойових дій в Україні.

У відповідності до мети нашої роботи нами було визначено такі завдання дослідження: 1) аналіз та узагальнення інформації з навчально-педагогічної літератури та електронних джерел доступних у Всесвітній мережі Інтернет щодо можливостей та особливостей застосування регбі як засобу фізкультурноспортивної реабілітації учасників бойових дій на Сході України; 2) виявлення рівня обізнаності та ступеню готовності фахівців спеціальності 017 «Фізична культура і спорт» до використання засобів регбі в системі ФСР учасників бойових дій в Україні.

Виклад основного матеріалу дослідження. У наших попередніх дослідженнях у співавторстві із Бабенко Д.С., Бойченко С.В. (вивчались питання готовності студентів-бакалаврату до участі у фізкультурно-спортивній реабілітації 3 використанням засобів футболу) [0]; Я.В. Кравченко (досліджувалися сучасні підходи до формування програм фізичної терапії військовослужбовців АТО з травмами нижніх кінцівок) [0], В.В. Правдивим (досліджувалися особливості фізична терапія чоловіків другого зрілого віку 3 компресійними переломами хребта у поперековому відділі внаслідок бойових дій на поліклінічному етапі та перевірено ефективність авторської програми терапевтичного впливу) [0], М.О. Тимощук (розглядались питання застосування спортивного орієнтування як ефективної складової комплексної фізкультурно-спортивної реабілітації (ФСР) ветеранів-військовослужбовців АТО і ОСС в Україні) [19] зазначалось, що травмовані учасники бойових дій під час реабілітаційного процесу з більшим задоволення обирають в процесі реабілітації та засоби, які для них є більш зручними та звичними (біг на довгі дистанції та спортивне орієнтування - $€$ звичними різновидами рухової активності 3 точки зору фізичної підготовки військовослужбовця, для професійно-орієнтованої діяльності підрозділів спецпризначення та ДШБ робота серед незнайомої місцевості, подолання довгих дистанції на місцевості iз використанням карти та компаса; спортивні ігри - також невід'ємна частина фізичної підготовки військових та засіб активного відпочинку, який сприяє фізичному та психо-емоційному відновленню організму; дозволяє навчитися різним варіантам комунікації та взаємодії в колективі; відпрацювати певні технічні та тактичні дії у невеликій групі військових, що в цілому позитивно впливає на їх подальшу професійно-спрямовану військову діяльність).

За офіційними даними, які нам надала Федерація Регбі України «для підвищення фізичних навичок десантників зі швидкості, спритності, витривалості, координації рухів та боротьби, в Десантно-штурмових військах (ДШВ) впроваджений новий олімпійський вид спорту - регбі-7» [0]. При цьому в Житомирі «з числа військовослужбовців 95-ої окремої десантно-штурмової бригади (ДШБ) - вже створена перша збірна команда ДШВ з цього виду спорту [17]. Ініціатива такого інноваційного впровадження в лавах українського десанту належить командувачу ДШВ ЗС України генерал-лейтенанту М. Забродському [0], який наголошує на тому, що «даний вид спорту активно 
застосовується в багатьох арміях країн світу та серед країн НАТО» [0]. Методичний супровід навчально-тренувального збору здійснюють представники Федерації регбі України (ФРУ) П. Рожков (координатор програми «Gets info Rugby»), Р. Горностай та О. Сморчков (тренери команди 3 регбі «Київські соколи») [0]. На думку тренерів, «окрім популяризації спорту та здорового способу життя, цей вид олімпійського спорту досить потрібний в підготовці десантників» [0].

Слід відзначити, що «регбі на візках, як вид спорту входить до програми Паралімпійських ігор та внесений до програми Міжнародних спортивних змагань «Invictus Games» [17]. 3 позицій сьогодення «одним iз найзахопливіших та найсуперечливіших видів спорту на Паралімпійських Іграх» вважають регбі на візках [9]. Часто можна почути, що регбі на візках називають «murderball» (дослівний переклад з англійської murder - вбивство, ball - м'яч). Але це не є об'єктивною думкою, і ось чому: в цьому виді спорту дозволено виступ змішаних команд (разом із дівчатами / жінками) найвідоміші спортсменки 2012 р. серед складу 8 команд-учасниць Паралімпіади - це Біке Кетельбутерс (Бельгія) та Кайлі Граймс (Великобрітанія) [9]. Регбі на візках в реаліях небезпечний вид спорту, а у відвідувачів матчів складається враження про те, що «будь-якого моменту спортсмени можуть отримати травму» [9]. Відповідним висновком може бути те, що «чим агресивніше та жорсткіше ти граєш, тим кращий результат»; ця думка виникнути може тому, що «надзвичайно агресивними, жорсткими виявилися (2012р.) 2 представників команди Австралії (Райлі Бетт, Кріс Бонд), саме вони забили мало не всі голи за збірну і принесли їй блискучу першу перемогу» [0; 0; 0]. На сьогодні постійно у Відкритому турнірі з регбі на візках серед осіб з ураженнями OPA в Україні приймають участь із 2017 р. [19] команди Житомирської та Київської областей, Рівного та Одеси.

У регбі на візках грають по 4 гравця в команді за правилами в яких поєдналися між собою правила із класичного регбі та американського футболу: грають команди намагаючись перетнути лінію суперника, який усіма можливими способами заважає це зробити - перетинаючи зону суперника м'яч повинен бути в руках або у візку [9; 0]. Гра проходить на баскетбольному майданчику. Регбі спортсменів на візках об'єднує елементи баскетболу, волейболу та хокею. Спортсмени грають у спеціально сконструйованих «гладіаторських» інвалідних візках. У грі використовується волейбольний м'яч, який можна нести, котити, кидати, передавати руками. М'яч не можна затримувати більше, ніж на 10 секунд.

На думку багатьох прихильників - агресія є невід'ємною частиною цього виду спорту. При цьому, якщо спортсмен під час зіткнення опиняється на підлозі, то вони зазвичай самостійно перекидаються на спину (в процесі гри вони прив'язують себе до візків пасками, щоб не випадати), тоді до нього підбігають 2 помічників зі спеціальним гумовим килимком і допомагають піднятися [9]. Спеціальні спортивні візки для регбі із алюмінію коштують близько 7000\$ (на вигляд дуже старі, пошарпані та не впадають в око необізнаній людини, але фахівці знають, що вони облаштовані спеціально для 
цього виду спорту). На офіційному сайті однієї 3 команд українських спортсменів зазначено, що здійснюється збір коштів для придбання спортивних візків де ціна 1 об’ єкта визначена в межах 2500-5000\$. Слід також уточнити, що для спортсменів із ураженнями ОРА існує 2 види візків: для нападників та захисників, одні йдуть на таран, а інші - обороняються (захисні мають спеціальні планки - їх вони просувають під візок суперника та перекидають їх; візки обладнані міні-бамперами та протекторами; колеса можна замінити за декілька секунд просто під час гри» [9; 18; 20].

Узагальнюючи інформацію щодо виникнення та розвитку адаптивного регбі (регбі на колясках) ми можемо констатувати наступне: 1) це командний вид спорту, який спеціально розробили для людей 3 травмами хребта в шийному відділі (тетраплегія); для людей 3 ампутаціями кінцівок, поліомієлітом та іншими захворюваннями, які вражають 3-и та більше кінцівок; 2) він успішно розвивається у більше ніж 28 країнах; 3) може претендувати на звання найвидовищнішим видом спорту в програмі літніх Паралімпійських ігор [9; 0; 0]. Також слід наголосити на тому, що в Україні і ще приблизно у декількох десятках країн цей вид адаптивного спорту «тільки починає свій активний розвиток» [9].

Слід зазначити, що у відповідності до Закону України «Про реабілітацію осіб 3 інвалідністю в Україні» [0] основними поняттями нашої роботи $\epsilon$ наступні: 1) види реабілітації у відповідності до Законодавства України це: медична реабілітація - це «система лікувальних заходів, що спрямовані на відновлення порушених чи втрачених функцій організму особи, на виявлення та активізацію компенсаторних можливостей організму з метою забезпечення умов для повернення особи до нормальної життєдіяльності, на профілактику ускладнень та рецидивів захворювання»; психолого-педагогічна реабілітація це «система психологічних та педагогічних заходів, спрямованих на формування способів оволодіння знаннями, уміннями і навичками, надання психологічної допомоги, зокрема щодо формування самоутвердження i належної самооцінки особою своїх можливостей, засвоєння правил суспільної поведінки шляхом здійснення системної навчально-виховної роботи»; професійна реабілітація - це «система заходів, спрямованих на підготовку особи до професійної діяльності, відновлення чи здобуття професійної працездатності шляхом адаптації, реадаптації, навчання, перенавчання чи перекваліфікації з можливим подальшим працевлаштуванням та необхідним соціальним супроводженням з урахуванням особистих здібностей та побажань особи»; трудова реабілітація - це «система заходів, розроблених 3 урахуванням здібностей, фізичних, розумових і психічних можливостей особи i спрямованих на оволодіння трудовими навичками забезпечення трудової діяльності та адаптацію у виробничих умовах, у тому числі шляхом створення спеціальних чи спеціально пристосованих робочих місць»; соціальна реабілітація - це «система заходів, спрямованих на створення і забезпечення умов для повернення особи до активної участі у житті, відновлення иї соціального статусу та здатності до самостійної суспільної і родинно-побутової діяльності шляхом соціально-середовищної орієнтації та соціально-побутової 
адаптації, задоволення потреби у забезпеченні технічними та іншими засобами реабілітації»; 2) грунтовними дефініціями нашого дослідження є: фізкультурноспортивна реабілітація (ФСР) - це система заходів, розроблених із застосуванням фізичних вправ для відновлення здоров'я особи та спрямованих на відновлення і компенсацію за допомогою занять ФКіС функціональних можливостей iї організму для покращення фізичного і психологічного стану; фізична реабілітація - це «система заходів, спрямованих на вироблення i застосування комплексів фізичних вправ на різних етапах лікування i реабілітації, що забезпечують функціональне відновлення особи, виявляють i розвивають резервні і компенсаторні можливості організму шляхом вироблення нових рухів, компенсаторних навичок, користування технічними та іншими засобами реабілітації, виробами медичного призначення».

Прес-служба Президента України повідомляє, що 23.08.2020 року Володимир Зеленський 23.08.2020 затвердив «Національну стратегію розвитку системи ФСР ветеранів війни та членів їхніх сімей, сімей загиблих (померлих) ветеранів війни» [0]. Цілі, етапи та їх основні завдання подано нами на рис. 1. Виступаючи на III Міжнародному волонтерському та ветеранському форуму «Там, де ми - там Україна», В. Зеленський підкреслив «необхідність покращення лікування та реабілітації учасників бойових дій» [0]. Він особливо зазначив, що «це не питання однієї визначної дати, вона має здійснюватися постійно, системно та послідовно, поза будь-яким політичним контекстом» [0].

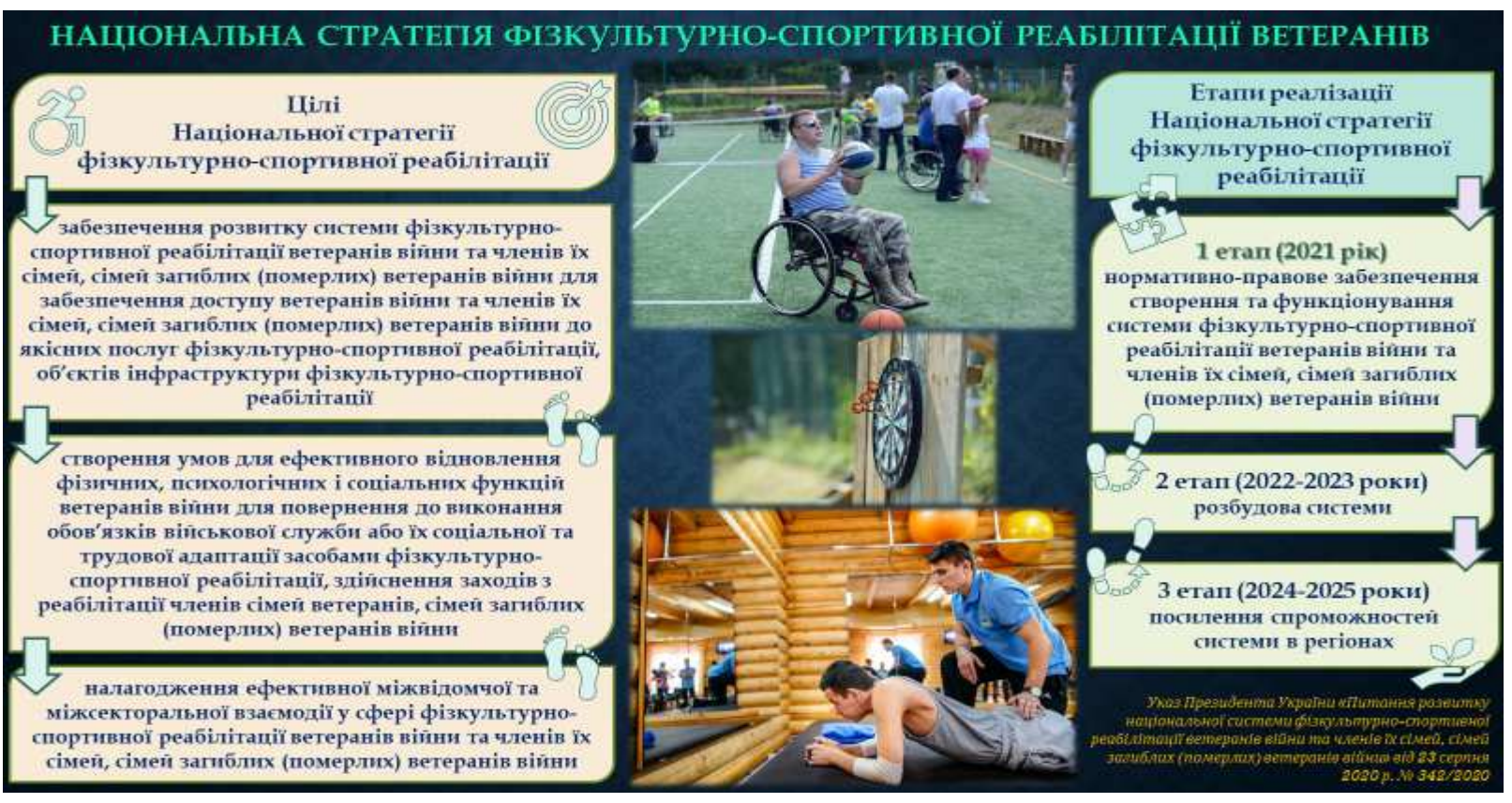

Рис. 1 Цілі та етапи Національної стратегії ФСР

О. Горбач зауважує, «що під час підготовчого періоду до ігор виявилася низка проблем таких як: наявна українська спортивна інфраструктура в регіональних містах, зокрема у Львові, Одесі та Києві фактично не пристосована для людей з особливими потребами; відсутні спеціальні пандуси та поручні; спортивні та оздоровчі комплекси не обладнані ліфтами, тому 
дістатися людині на візку до басейну практично не можливо та інші» [11]. За іiі словами «в окремих містах України ведеться певна робота в напрямку покращення умов для населення, проте робиться це переважно силами волонтерських або ветеранських організацій та має несистемний характер» [11]. Ми погоджуємося 3 думкою про те, що стан матеріально-технічного забезпечення адаптивних видів спорту в Україні, можливість реалізації рекреаційно-оздоровчих потреб для осіб з особливими рухливими, серед яких сьогодні одне 3 провідних місць займає група поранених ветеранів АТО/ООС, знаходиться у вкрай незадовільному стані, особливо це стосується регіонів.

У 2017 р. Україна вперше приєдналася до «Ггри нескорених» (Invictus Games), які були засновані британським принцом Гаррі як параспортивні змагання для військових, поранених під час виконання бойових завдань або проходження військової служби [0]. Головне завдання «Invictus», це звичайно не лише спорт, це передусім повернення постраждалих ветеранів до активного життя [0]. За словами О. Горбач, «спорт, навіть не в рамках Міжнародних змагань, стає для учасників бойових дій певним поштовхом приводити себе до ладу, відновлювати спілкування з іншими людьми - це допомагає інтегруватися назад до суспільства».

3 важливим значенням спорту в цілому, як інструменту реабілітації погоджується М. Колесник [0]: «у нас взагалі паралімпійці або ті, хто беруть участь в Invictus Games - це люди з необмеженими можливостями»; «нажаль, $є$ факт сьогодення - недоопрацювання обласних державних адміністрацій, через низьку зацікавленість в таких проектах та необізнаність». За словами М. Колесника, іноді коли змагання відбуваються у регіонах «хлопці шикуються на відбіркові змагання, а у них навіть відсутня форма; тому С. Гордєєв навмисно вдягнув камуфляж, в якому був у Дебальцеве» [0]. Хлопці на візках вимушені їхати туди в Україні, де їм надають умови для тренувань, бо не завжди на місцях можуть створити належні умови. Але фондів, 3 яких вони можуть отримати ресурси на інвентар, зарплату в державі немає. Зараз ведеться робота над створенням цієї системи [0]. Часто байдужість чиновників на рівні регіонів призводить до того, що хлопці знаходять інші виходи «із своїх проблем» через алкоголь, наркотики тощо. Більшість же ветеранів сьогодні які брали участь у Іграх в Торонто, не зважаючи на те, що мають проблеми із працевлаштуванням готові «продовжити займатися спортом або тренувати побратимів» та долучатися до нових проектів ФСР. «Ми не повинні залишати їх сам на сам зі своїми проблемами; саме тому спортивна програма реабілітації $\epsilon$ дуже серйозною мотивацією для тих, хто зараз знаходиться на передовій. Вони бачать, що поранених не покидають, дбають про родини загиблих. Вони мають знати що, в разі отримання інвалідності в них не буде проблем, а буде повноцінне життя». М. Колесник вважає [0], що це дуже важливий етап реабілітації, можливо найкращий з того, що собі може дозволити Україна: «спорт, тренування, спільна мета - це демонстрація того, що вони не безпорадні, а впевнені у собі і в майбутньому».

Закордонний досвід свідчить про те, що в Канаді «кожен військовий, який має поранення чи ампутації і потребує щось на кшталт велосипеда, просто 
може скласти заявку з обгрунтуванням і держава надає необхідні кошти»; «на необхідності залучення поранених військових до активного життя наполягає Шайло Гарріс, колишній штаб-сержант 10ої гірсько-піхотної дивізії армії США, який отримав мінно-вибухове ураження в Іраку о 2007 р., після він проходив довгу та складну реабілітацію, але найбільш запеклою була боротьба із ПТРС; а сьогодні він $\epsilon$ автором книги «Сталева воля: моя подорож крізь пекло, аби стати тією людиною, якою я мав стати», активно подорожує, виступаючи 3 мотиваційними тренінгами для поранених військових»; за його словами «армії в усьому світі певним чином готують своїх бійців до загибелі, але абсолютно не вчать, як жити після отримання важких поранень»; його дружина (психолог Джеймі Панізза-Кімболл) підкреслює, що вирішенням проблеми може бути «проведення усіляких соціальних заходів за участю ветеранів; замість того, щоб ховатися у собі і залишатися сам на сам зі своїм горем та проблемами необхідно збиратися та спілкуватися з побратимами, навіть в неформальній обстановці, оскільки «чай, кава та печиво та щире спілкування, дружня, тепла підтримка можуть зробити більше ніж спеціалісти»»; «важливим для України $\epsilon$ американський досвід залучення приватного сектору до вирішення проблем ветеранів - громадських фондів, волонтерських організацій, суспільства, місцевих керівників, оскільки не всі питання ФСР має вирішувати держава на загальнонаціональному рівні» [11].

У нашому дослідженні протягом 2019-2020 навчального року взяли участь 244 бакалаврів та 33 магістранти спеціальності 017 «Фізична культура і спорт» Національного університету фізичного виховання і спорту України (НУФВСУ); 246 офіцерів денної та 392 офіцери заочної форм навчання - випускників магістратури ОТР та 10 бакалаврів (начальники ФПіС) Національного університету оборони України імені Івана Черняховського (НУОУ імені Івана Черняховського).

В таблиці 1 нами представлені дані отримані під час констатувального опитування щодо ступеню обізнаності фахівців спеціальності 017 «ФКіС» щодо застосування засобів регбі як засобу ФСР учасників бойових дій в Україні:

1) $42,42 \%$ магістрантів та 57,79\% бакалаврів НУФВСУ, а також $39,5 \%$ магістрантів та 40\% бакалаврів НУОУ імені Івана Черняховського вважають, що «мають поодинокі теоретичні відомості, але хотів би при нагоді отримати більш грунтовну інформацію із особливостей застосування регбі як засобу ФСР для осіб з інвалідністю в умовах сучасного суспільства»; 
Таблиця 1

Результати опитування щодо виявлення ступеня обізнаності фахівців спеціальності 017 «Фізична культура і спорт» щодо застосування засобів регбі як засобу ФСР учасників бойових дій в Україні (\%)

\begin{tabular}{|c|c|c|c|c|c|c|c|c|}
\hline \multirow{2}{*}{ ЗМІСТ ПИТАННЯ } & \multicolumn{8}{|c|}{ Варіанти відповідей } \\
\hline & $\mathrm{A}$ & $\mathrm{B}$ & $\mathrm{C}$ & $\mathrm{D}$ & A & $\mathrm{B}$ & $\mathrm{C}$ & $\mathrm{D}$ \\
\hline \multirow{4}{*}{$\begin{array}{l}\text { 1.«Чи відомі Вам особливості } \\
\text { застосування регбі як засобу ФСР для } \\
\text { осіб з інвалідністю в умовах сучасного } \\
\text { суспільства»?: «А»- - «так, відомі»; «В»- } \\
\text { «ні, не відомі»; «С»- мають поодинокі } \\
\text { теоретичні відомості, але хотів би при } \\
\text { нагоді отримати більш грунтовну } \\
\text { інформацію із цього питання; «D»- } \\
\text { важко відповісти }\end{array}$} & \multicolumn{4}{|c|}{ Магістранти НУФВСУ } & \multicolumn{4}{|c|}{ Бакалаври НУФВСУ } \\
\hline & 21,21 & 9,09 & 42,42 & 27,27 & 3,28 & 21,31 & 57,79 & 17,62 \\
\hline & \multicolumn{4}{|c|}{$\begin{array}{l}\text { Магістри НУОУ імені Івана } \\
\text { Черняховського }\end{array}$} & \multicolumn{4}{|c|}{$\begin{array}{c}\text { Бакалаври НУОУ імені Івана } \\
\text { Черняховського } \\
\end{array}$} \\
\hline & 9,56 & 33,07 & 39,50 & 17,87 & 10 & 30 & 40 & 20 \\
\hline \multirow{4}{*}{$\begin{array}{l}\text { 2. «Чи маєте Ви достатньо теоретичних } \\
\text { та методичних відомостей щодо } \\
\text { особливостей реалізації засад та } \\
\text { впровадження засобів ФСР в Україні та } \\
\text { світі»?: «А»- «так, маю»; «В»- -ні, не } \\
\text { маю»; «С» - вважаю необхідним } \\
\text { створення спеціальних НМК про } \\
\text { особливостей застосування засобів регбі } \\
\text { у ФСР, в тому числі в } \\
\text { військовослужбовців із наслідками } \\
\text { бойової травми; «D»-важко відповісти }\end{array}$} & \multicolumn{4}{|c|}{ Магістри НУФВСУ } & \multicolumn{4}{|c|}{ Бакалаври НУФВСУ } \\
\hline & 33,33 & 6,06 & 42,42 & 18,18 & 19,67 & 7,79 & 63,52 & 9,02 \\
\hline & \multicolumn{4}{|c|}{$\begin{array}{c}\text { Магістри НУОУ імені Івана } \\
\text { Черняховського }\end{array}$} & \multicolumn{4}{|c|}{$\begin{array}{c}\text { Бакалаври НУОУ імені Івана } \\
\text { Черняховського }\end{array}$} \\
\hline & 3,29 & 7,52 & 75,39 & 13,79 & 30 & 20 & 40 & 10 \\
\hline \multirow{4}{*}{$\begin{array}{l}\text { 3. «Чи маєте Ви практичні уміння та } \\
\text { навички щодо реалізації засад ФСР, } \\
\text { зокрема із використанням засобів } \\
\text { регбі»?: «А»- «так, маю»; «В»- -ні, не } \\
\text { маю»; «С» - вважаю необхідним } \\
\text { створення спеціалізованих заходів під } \\
\text { час яких можна було оволодівати } \\
\text { практичним уміннями та навичками } \\
\text { щодо реалізації засобів ФСР, в тому } \\
\text { числі військовослужбовців із наслідками } \\
\text { бойової травми; «D»-важко відповісти }\end{array}$} & \multicolumn{4}{|c|}{ Магістри НУФВСУ } & \multicolumn{4}{|c|}{ Бакалаври НУФВСУ } \\
\hline & 6,06 & 21,21 & 54,55 & 18,18 & 13,52 & 23,77 & 44,67 & 18,03 \\
\hline & \multicolumn{4}{|c|}{$\begin{array}{c}\text { Магістри НУОУ імені Івана } \\
\text { Черняховського }\end{array}$} & \multicolumn{4}{|c|}{$\begin{array}{c}\text { Бакалаври НУОУ імені Івана } \\
\text { Черняховського }\end{array}$} \\
\hline & 1,88 & 11,13 & 70,69 & 16,30 & 10 & 60 & 20 & 10 \\
\hline \multirow{4}{*}{$\begin{array}{l}4 . \text { «Чи вважаєте Ви необхідним } \\
\text { проведення спеціалізованих, професійно- } \\
\text { спрямованих тренінгів, МК, відкритих } \\
\text { занять / тренувань для грунтовного } \\
\text { оволодіння інформацією та практичним } \\
\text { досвідом з питань реалізації ФСР»?: «А» } \\
\text { - «так, вважаю це актуальним питанням } \\
\text { сьогодення»; «В»- «ні, не вважаю»; «С» } \\
\text { - вважаю, що це було доречно, оскільки } \\
\text { в сучасному суспільстві є соціальний } \\
\text { запит на проведення якісних, } \\
\text { систематичних заходів ФС із } \\
\text { учасниками бойових дій, які мають } \\
\text { наслідки бойової травми, із членами } \\
\text { поранених та загиблих родин; створення } \\
\text { системи ФСР в Україні; «D»- важко } \\
\text { відповісти }\end{array}$} & \multicolumn{4}{|c|}{ Магістри НУФВСУ } & \multicolumn{4}{|c|}{ Бакалаври НУФВСУ } \\
\hline & 10 & 24,24 & 45,45 & 12,12 & 17,21 & 2,05 & 68,03 & 12,70 \\
\hline & \multicolumn{4}{|c|}{$\begin{array}{c}\text { Магістри НУОУ імені Івана } \\
\text { Черняховського }\end{array}$} & \multicolumn{4}{|c|}{$\begin{array}{c}\text { Бакалаври НУОУ імені Івана } \\
\text { Черняховського } \\
\end{array}$} \\
\hline & 22,57 & 2,19 & 71,79 & 3,45 & 40 & 0 & 60 & 0 \\
\hline
\end{tabular}

2) $42,42 \%$ магістрантів та $63,52 \%$ бакалаврів НУФВСУ і $75,39 \%$ магістрантів та 40\% бакалаврів НУОУ імені Івана Черняховського «вважають необхідним створення спеціальних НМК про особливостей застосування 
засобів ребгі у ФСР, в тому числі в військовослужбовців із наслідками бойової травми»;

3) 54,55\% магістрантів та 44,67\% бакалаврів НУФВСУ, а також 70,69\% магістрантів НУОУ імені Івана Черняховського вважають необхідним створення спеціалізованих заходів під час яких можна було оволодівати практичним уміннями та навичками щодо реалізації засобів ФСР, в тому числі військовослужбовців із наслідками бойової травми;

4) $22,57 \%$ магістрантів та 40\% бакалаврів НУОУ імені Івана Черняховського вважаю це актуальним питанням сьогодення проведення спеціалізованого навчання; 45,45\% магістрантів та 68,03\% бакалаврів НУФВСУ, а також 71,79\% магістрантів та 60\% бакалаврів НУОУ імені Івана Черняховського підкреслили під час опитування, що дуже доречним $\epsilon$ проведення спеціалізованого навчання, оскільки в сучасному суспільстві $\epsilon$ соціальний запит на проведення якісних, систематичних заходів ФСР із учасниками військових локальних конфліктів із наслідками бойової травми, із членами родин поранених та загиблих військовослужбовців; наголошують на необхідності створення системи ФСР в Україні.

Таким чином можемо констатувати, що більшість випускників бакалаврів та магістрів вважають доцільним обгрунтування та розробку системи ФСР в Україні; наголошують на необхідності створення спеціалізованих професійноспрямованих методичних комплексів, які б характеризували та розкривали особливості системи ФСР, зокрема особливості застосування засобів регбі у відновленні здоров’я військовослужбовців із наслідками бойової травми; вважають необхідним відвідування спеціалізованих заходів, тренінгів, МК під час яких можна оволодіти практичними уміннями та навичками щодо впровадження засобів ФСР під контролем науковців, фахівців та тренерів Федерації Регбіліг України та Національної ради спортивної реабілітації захисників України.

Висновки і перспективи подальших досліджень розвитку в цьому напрямі: отримані результати нашого педагогічного дослідження можуть бути використані під час викладання навчальних дисциплін для студентівбакалаврату та магістрантів студентів НУОУ імені Івана Черняховського та НУФВСУ; планується розробка комплексу професійно-спрямованих навчальнометодичних матеріалів для фахівців спеціальності 017.

\section{ЛІТЕРАТУРА}

1. Бабенко Д.С., Юденко О.В., Бойченко С.В. Готовність студентів-бакалаврату до участі у фізкультурно-спортивній реабілітації 3 використанням засобів футболу // «Теоретико-методичні аспекти фізичної культури $i$ спорту» : Матеріали науковопрактичної конференції з міжнародною участю [Збірка матеріалів]. Івано-Франківськ Київ: НУФВСУ [електронний ресурс]. 2020. С. 35-44. URL : https://unisport.edu.ua/sites/default/files/vseDocumenti/zbirka_konferenciyi_-_ivano-frankivskkyyiv_28.05.2020.pdf.

2. Бриндюков Ю.Л. Теорія і практика реабілітації військовослужбовців - учасників бойових дій в системі соціальних служб. дисертація на здобуття наукового ступеня доктора педагогічних наук; 13.00.05 - соціальна педагогіка Хмельницький-Тернопіль. 2018. 559 с. 
3. Гріненко Ю.О. Реабілітація ветеранів АТО: як повернути до мирного життя кожного. 23.11.2016/ URL: https:/socportal.info/2016/11/23/reabilitatsiya-veteraniv-ato-yak-povernuti-domirnogo-zhittya-kozhnogo.html

4. Гулиев М.И. Инвалидность вследствие военной травмы в Азербайджанской Республике и медико-социальная реабилитация инвалидов: Автореф. дис. ...канд. мед.наук. М., 2004. 26 c.

5. Дегтяренко Т.М. Теоретико-методологічні засади управління системою корекційнореабілітаційної допомоги особам з психофізичними порушеннями [Текст] : автореф. дис. ... д-ра пед. наук : 13.00.03 / Дегтяренко Тетяна Миколаївна ; Ін-т спец. педагогіки НАПН України. К., 2012. 43 с.

6. Закон України Про реабілітацію осіб з інвалідністю в Україні. (Документ 2961-IV, чинний, поточна редакція - від 01.01.2020). URL : https://zakon.rada.gov.ua/laws/show/2961-15\#Text

7. Кокун О.М., Агаєв Н.А., Пішко I.О., Лозінська Н.С., Остапчук В.В. Психологічна робота з військовослужбовцями - учасниками АТО на етапі відновлення: Методичний посібник. К.: НДЦ ГП ЗСУ, 2017. 282 с.

8. Корчагина Е.В. Последствия боевой черепно-мозговой травмы и ограничение жизнедеятельности у бывших военнослужащих трудоспособного возраста в современных условиях: Автореф. дис. ... канд. мед. наук. СанктПетербург, 2008.

9. Кравець А. Паралімпіада: «вбивче» регбі на візках. // ВВС Україна, Лондон. 6 вересня, 2012. URL: https://www.bbc.com/ukrainian/sport/2012/09/120906_murderball_paralympics_dt

10. Кравченко Я.В., Юденко О.В. Сучасні підходи до формування програм фізичної терапії військовослужбовців АТО 3 травмами нижніх кінцівок // Науковий часопис. Національного педагогічного університету імені М.П. Драгоманова Серія 15. «Науковопедагогічні проблеми фізичної культури / Фізична культура і спорт». зб. наукових праць / за ред. О.В. Тимошенка. К. : вид-во НПУ імені М.П. Драгоманова, 2019; 3(115 С)19: 58-63.

11. Лапаєв Ю. Рецепт реабілітації: Ініціатива в регіонах, спорт та активні ветерани. Тиждень.UA. 13 жовтня 2017. URL : https://tyzhden.ua/Society/201873

12. Особливості медико-соціальної експертизи та реабілітації інвалідів військової служби та учасників антитерористичної операції: Методичні рекомендації. / Уклад.: В.І. Шевчук, В.В. Кравченко, Н.М. Беляєва, О.Б. Яворовенко. Вінниця 2016. 43 с.

13. Офіційна сторінка «Київського міського центру 3 фізичної культури і спорту інвалідів «Інваспорт»». URL : https://www.invasport.kiev.ua/ua/bukh/879-fizkulturno-sportivnareabilitatsiya-cherven-2020

14. Офіційна сторінка підприємства «MediLine». Обладнання для активної реабілітації. URL : https://ml.com.ua/product-category/posttravmatychna-reabilitatsiya/aktyvna-reabilitatsiya/

15. Правдивий В.В. Фізична терапія чоловіків другого зрілого віку з компресійними переломами хребта у поперековому відділі внаслідок бойових дій на поліклінічному етапі : магістерська наукова робота зі спеціальності 227 «Фізична терапія, ерготерапія». Київ : НПУ імені М.П. Драгоманова, 2019. 120 с.

16. Президент затвердив стратегію фізкультурно-спортивної реабілітації ветеранів війни. 23.08.2020. URL : https://uatv.ua/prezydent-zatverdyv-strategiyu-rozvytku-fizkulturnosportyvnoyi-reabilitatsiyi-veteraniv-vijny/

17. У Десантно-штурмових військах 3С України впроваджений новий олімпійський вид спорту - регбі-7. 04 квітня 2019. URL: http://www.5kolec.com/rugby/news/article-59326/

18. У Житомирі відбувся відкритий турнір Житомирської області з регбі на візках. 31.10.2017. URL : https://invak.info/sport/u-zhitomiri-vidbuvsya-vidkritij-turnir-zhitomirskoyioblasti-z-regbi-na-vizkakh-foto.html

19. Юденко О.В., Тимощук М.О. Спортивне орієнтування як ефективна складова комплексної фізкультурно-спортивної реабілітації ветеранів-військовослужбовців АТО і ОСС в Україні. // «Теоретико-методичні аспекти фізичної культури і спорту» : Матеріали науково-практичної конференції 3 міжнародною участю [Збірка матеріалів]. ІваноФранківськ - Київ: НУФВСУ [електронний ресурс]. 2020; 88-96. URL: 
https://uni-sport.edu.ua/sites/default/files/vseDocumenti/zbirka_konferenciyi_-_ivano-frankivskkyyiv_28.05.2020.pdf

20. Шуткевич О. У Вінниці відбувся чемпіонат з регбі на візках. 17 жовтня 2019. URL: https://m.day.kyiv.ua/uk/news/171019-u-vinnyci-vidbuvsya-chempionat-z-regbi-na-vizkah

\section{REFERENCES}

1. Babenko D.S., Yudenko O.V., Boichenko S.V. Hotovnist studentiv-bakalavratu do uchasti u fizkulturno-sportyvnii reabilitatsii z vykorystanniam zasobiv futbolu // «Teoretyko-metodychni aspekty fizychnoi kultury i sportu»: Materialy naukovo-praktychnoi konferentsii z mizhnarodnoiu uchastiu [Zbirka materialiv]. Ivano-Frankivsk - Kyiv: NUFVSU [elektronnyi resurs]. 2020. S. 35-44. URL: https://uni-sport.edu.ua/sites/default/files/vseDocumenti/zbirka_konferenciyi_-_ivano-frankivskkyyiv_28.05.2020.pdf

2. Bryndiukov Yu.L. Teoriia i praktyka reabilitatsii viiskovosluzhbovtsiv - uchasnykiv boiovykh dii v systemi sotsialnykh sluzhb. dysertatsiia na zdobuttia naukovoho stupenia doktora pedahohichnykh nauk; 13.00.05 - sotsialna pedahohika Khmelnytskyi-Ternopil. 2018. 559 s.

3. Hrinenko Yu.O. Reabilitatsiia veteraniv ATO: yak povernuty do myrnoho zhyttia kozhnoho. 23.11.2016/ URL : https://socportal.info/2016/11/23/reabilitatsiya-veteraniv-ato-yak-povernuti-domirnogo-zhittya-kozhnogo.html

4. Hulyev M.Y. Ynvalydnost vsledstvye voennoi travmy v Azerbaidzhanskoi Respublyke y medyko-sotsyalnaia reabylytatsyia ynvalydov: Avtoref. dys. ...kand. med.nauk. M., 2004. 26 s.

5. Dehtiarenko T.M. Teoretyko-metodolohichni zasady upravlinnia systemoiu korektsiinoreabilitatsiinoi dopomohy osobam z psykhofizychnymy porushenniamy [Tekst] : avtoref. dys. ... dra ped. nauk : 13.00 .03 / Dehtiarenko Tetiana Mykolaivna ; In-t spets. pedahohiky NAPN Ukrainy. K., 2012. $43 \mathrm{~s}$.

6. Zakon Ukrainy Pro reabilitatsiiu osib z invalidnistiu v Ukraini. (Dokument 2961-IV, chynnyi, potochna redaktsiia - vid 01.01.2020). URL: https://zakon.rada.gov.ua/laws/show/2961-15\#Text

7. Kokun O.M., Ahaiev N.A., Pishko I.O., Lozinska N.S., Ostapchuk V.V. Psykholohichna robota z viiskovosluzhbovtsiamy - uchasnykamy ATO na etapi vidnovlennia: Metodychnyi posibnyk. K.: NDTs HP ZSU, 2017. $282 \mathrm{~s}$.

8. Korchahyna E.V. Posledstvyia boevoi cherepno-mozghovoi travmy y ohranychenye zhyznedeiatelnosty u byvshykh voennosluzhashchykh trudosposobnoho vozrasta v sovremennykh uslovyiakh: Avtoref. dys. ... kand. med. nauk. SanktPeterburh, 2008.

9. Kravets A. Paralimpiada: «vbyvche» rehbi na vizkakh. // VVS Ukraina, London. 6 veresnia, 2012. URL : https://www.bbc.com/ukrainian/sport/2012/09/120906_murderball_paralympics_dt

10. Kravchenko Ya.V., Yudenko O.V. Suchasni pidkhody do formuvannia prohram fizychnoi terapii viiskovosluzhbovtsiv ATO z travmamy nyzhnikh kintsivok // Naukovyi chasopys. Natsionalnoho pedahohichnoho universytetu imeni M.P. Drahomanova Seriia 15. «Naukovo-pedahohichni problemy fizychnoi kultury / Fizychna kultura i sport». zb. naukovykh prats / za red. O.V. Tymoshenka. K. : vyd-vo NPU imeni M.P. Drahomanova, 2019; 3(115 S)19: 58-63.

11. Lapaiev Yu. Retsept reabilitatsii: Initsiatyva $\mathrm{v}$ rehionakh, sport ta aktyvni veterany. Tyzhden.UA. 13 zhovtnia 2017. URL : https://tyzhden.ua/Society/201873

12. Osoblyvosti medyko-sotsialnoi ekspertyzy ta reabilitatsii invalidiv viiskovoi sluzhby ta uchasnykiv antyterorystychnoi operatsii: Metodychni rekomendatsii. / Uklad.: V.I. Shevchuk, V.V. Kravchenko, N.M. Beliaieva, O.B. Yavorovenko. Vinnytsia 2016. 43 s.

13. Ofitsiina storinka «Kyivskoho miskoho tsentru z fizychnoi kultury i sportu invalidiv «Invasport»». URL : https://www.invasport.kiev.ua/ua/bukh/879-fizkulturno-sportivnareabilitatsiya-cherven-2020

14. Ofitsiina storinka pidpryiemstva «MediLine». Obladnannia dlia aktyvnoi reabilitatsii. URL : https://ml.com.ua/product-category/posttravmatychna-reabilitatsiya/aktyvna-reabilitatsiya/

15. Pravdyvyi V.V. Fizychna terapiia cholovikiv druhoho zriloho viku z kompresiinymy perelomamy khrebta u poperekovomu viddili vnaslidok boiovykh dii na poliklinichnomu etapi : mahisterska naukova robota zi spetsialnosti 227 «Fizychna terapiia, erhoterapiia». Kyiv : NPU imeni M.P. Drahomanova, 2019. 120 s. 
16. Prezydent zatverdyv stratehiiu fizkulturno-sportyvnoi reabilitatsii veteraniv viiny. 23.08.2020. URL : https://uatv.ua/prezydent-zatverdyv-strategiyu-rozvytku-fizkulturnosportyvnoyi-reabilitatsiyi-veteraniv-vijny/

17. U Desantno-shturmovykh viiskakh ZS Ukrainy vprovadzhenyi novyi olimpiiskyi vyd sportu - rehbi-7. 04 kvitnia 2019. URL : http:/www.5kolec.com/rugby/news/article-59326/

18. U Zhytomyri vidbuvsia vidkrytyi turnir Zhytomyrskoi oblasti $\mathrm{z}$ rehbi na vizkakh. 31.10.2017. URL : https://invak.info/sport/u-zhitomiri-vidbuvsya-vidkritij-turnir-zhitomirskoyioblasti-z-regbi-na-vizkakh-foto.html

19. Yudenko O.V., Tymoshchuk M.O. Sportyvne oriientuvannia yak efektyvna skladova kompleksnoi fizkulturno-sportyvnoi reabilitatsii veteraniv-viiskovosluzhbovtsiv ATO i OSS v Ukraini. // «Teoretyko-metodychni aspekty fizychnoi kultury i sportu» : Materialy naukovopraktychnoi konferentsii z mizhnarodnoiu uchastiu [Zbirka materialiv]. Ivano-Frankivsk - Kyiv: NUFVSU [elektronnyi resurs]. 2020; 88-96. https://uni-sport.edu.ua/sites/default/files/vseDocumenti/zbirka_konferenciyi_-_ivano-frankivskkyyiv_28.05.2020.pdf

20. Shutkevych O. U Vinnytsi vidbuvsia chempionat $z$ rehbi na vizkakh. 17 zhovtnia 2019. URL: https://m.day.kyiv.ua/uk/news/171019-u-vinnyci-vidbuvsya-chempionat-z-regbi-na-vizkah

\section{PЕЗЮМЕ}

Оксана Юденко,
кандидат педагогических наук,
доцент кафедры профессионального,
неолимпийского и адаптивного спорта
Национального университета физического
воспитания и спорта Украины
Артур Мартиросян,
кандидат наук по физическому
воспитанию и спорту, доцент;
президент Украинской Федерации регбилиг,
тренер национальной сборной Украины по регбилиг
Александр Петрачков,
кандидат педагогических наук, доцент, полковник
Учебно-научный институт физической
культуры и спортивно-оздоровительных технологий
Национального университета обороны Украины
имени Ивана Черняховского
Алина Белоус,
магистрант кафедры профессионального,
неолимпийского и адаптивного спорта
Национального университета физического
воспитания и спорта Украины

\section{Готовность специалистов специальности 017 «Физическая культура и спорт» к использованию средств регби в системе физкультурно-спортивной реабилитации участников боевых действий в Украине}

С 2014 года (начала военного конфликта на Востоке Украины) с каждым годом все более и более возрастает потребность в специалистах, которые могли бы качественно и эффективно возвращчать военнослужащцих - участников боевых действий к жизни на мирной территории, а также справляться с последствиями боевой травмы средствами физической и ФСР. 
Некоторые аспекты использования различных видов реабилитащии у военнослужащих с последствиями боевой травмы раскрыты в работах таких ученых как Ю.Л. Бриндюкова, Т.М. Дегтяренко, М.И. Гулиева, О.В. Кочаргиной и др. К сожалению при исследовании литературных источников нами вылвлено следующее: практически отсутствуют теоретические и методические сведения, которые давали бы четкие представления об особенностях использования средств некоторых видов адаптивного спорта, в том числе и регби, как средства ФСР участников боевых действий с дисфункииями вследствие боевой травмы.

Цель статьи: выявление степени готовности специиалистов специальности 017 «Физическая культура и спорт» к использованию средств регби в системе ФСР участников боевых действий в Украине. Задания исследования: 1) анализ и обобщение информации из учебно-педагогической литературы и электронных источников, относительно возможностей и особенностей использования средств регби как средства ФСР участников боевых действий на Востоке Украины; 2) выявление уровня осведомленности и степени готовности специалистов 017 «Физическая культура и спорт» к использованию средств регби в системе ФСР участников боевых действий в Украине.

Графически авторы представили Цели и этапь «Национальной стратегии развития системы ФСР ветеранов войны и членов их семей, семей погибших ветеранов войныл» которая утверждена 23.08.2020 Президентом Украины В. Зеленским. Понятие ФСР в соответствии с Законом Украинь про реабилитацию людей с инвалидностью следует трактовать как «систему мероприятий, разработанных с применением физических упражнений для восстановления здоровья человека и направленных на восстановление $u$ компенсацию с помощью занятий физической культурой и спортом функциональных возможностей его организма для улучшения физического и психологического состояния».

В исследовании принимали участие студенть НУФВСУ и НУОУ имени Ивана Черняховского в 2020 2. Результать опроса выявили очень низкий уровень овладения теоретическими сведениями и практически полное отсутствие практических навыков и умений относительно использования средств ФСР для коррекичи последствий боевой травмы у участников боевых действий; будущчие специалисты утверждают, что хотели бы иметь более детальную информацию по вопросу ФСР; они хотел бы для этого посещать специализированные тренинги, семинары или мастер-классы, которые бы проводились специалистами отдельных федераций, научно-педагогическими сотрудниками ВНЗ $и$ специалистами Национального Совета спортивной реабилитащии защчитников Украины.

На основании проводимых сейчас и в дальнейшем исследований планируется усовершенствование учебно-методического комплекса для будущих специалистов специальности 017 «Физическая культура и спорт»; могут использоваться специалистами, которые решают профессиональные задачи с военнослужащими, которые имеют дисфункиии вследствие боевой травмы.

Ключевые слова: готовность; специалисты; физическая культура и спорт; средства; физкультурно-спортивная реабилитаџия; участники; боевые действия.

\section{SUMMARY}

Yudenko Oksana,

Candidate of Pedagogical Sciences, Associate Professor of the Department of Professional, Non-Olympic and Adaptive Sports of the National University of Physical Education and Sport of Ukraine Artur Martirosyan, President of the Ukrainian Rugby Federation,

Candidate of Sciences in Physical Education and Sports, Associate Professor; coach of the national rugby team of Ukraine 
Oleksandr Petrachkov,

Candidate of Pedagogical Sciences, Associate Professor, Master of Sports of Ukraine in rugby; colonel; Educational and Scientific Institute of Physical Culture and

Sports and Health Technologies of the

National University of Defense

Alina Bilous,

Master's student of the Department of Professional,

Non-Olympic and Adaptive Sports of the National University of Physical

Education and Sport of Ukraine

\section{Readiness of specialists of specialty 017 «Physical Culture and Sports» to use rugby in the system of physical culture and sports rehabilitation of combatants in Ukraine}

Since 2014 (the beginning of the military conflict in eastern Ukraine), the need for specialists who could effectively and efficiently return combatants to life in a peaceful territory, as well as cope with the consequences of combat trauma by means of physical and FSR.

Some aspects of the use of various types of rehabilitation in servicemen with the consequences of combat trauma are revealed in the works of such scientists as Yu.L. Brindyukova, T.M. Degtyarenko, M.I. Gulieva and other specialists. Unfortunately, a study of the literature revealed the following: there is almost no theoretical and methodological information that would give a clear idea of the features of the use of some adaptive sports, including rugby, as a means of FSR participants in hostilities due to dysfunction due to combat injury.

The purpose of the article: to identify the degree of readiness of specialists in the specialty 017 «Physical Culture and Sports» to use rugby in the FSR system of combatants in Ukraine. Tasks of the study: 1) analysis and generalization of information from educational and pedagogical literature and electronic sources on the possibilities and features of the use of rugby as a means of FSR participants in hostilities in eastern Ukraine; 2) identification of the level of awareness and the degree of readiness of specialists 017 «Physical Culture and Sports» for the use of rugby in the FSR system of participants in hostilities in Ukraine.

Graphically, the authors presented the Goals and stages of the «National strategy for the development of the FSR system of war veterans and members of their families, families of deceased war veterans» which was approved on 23.08.2020 by the President of Ukraine V. Zelensky. The concept of FSR in accordance with the Law of Ukraine on Rehabilitation of People with Disabilities should be interpreted as "a system of activities developed using exercise to restore human health and aimed at recovery and compensation through exercise and sports functional capabilities of his body to improve physical and psychological state».

The study involved students of NUFVSU and NUOU named after Ivan Chernyakhovsky in 2020. The results of the survey revealed a very low level of mastery of theoretical information and almost complete lack of practical skills and abilities to use the FSR to correct the consequences of combat trauma in combatants; future experts say they would like more information on the FSR; For this purpose, they would like to attend specialized trainings, seminars or master classes, which would be conducted by specialists of individual federations, scientific and pedagogical staff of universities and specialists of the National Council for Sports Rehabilitation of Defenders of Ukraine.

On the basis of current and further research, it is planned to improve the educational and methodological complex for future specialists in the specialty 017 «Physical Culture and Sports»; can be used by specialists who solve professional problems with servicemen who have dysfunctions due to combat trauma.

Key words: readiness; specialists; physical culture and sports; means; physical culture and sports rehabilitation; participants; hostilities. 